\title{
A Linguistic Study of Depression in Religious Texts
}

\author{
Prof. Dr. Riyadh Tariq Kadhim Al-Ameedi \\ alameedi.rtk@gmail.com \\ Department of English, College of Education for Human Sciences, University of Babylon
}

\author{
Noor Al-Huda Kadhim Hussein \\ alhusseininoor688@gmail.com \\ PhD Student, Department of English, College of Education for Human Sciences, University of Babylon
}

\begin{abstract}
Studies on the importance of language and verbalism in depression are still challenging. Thus, the present study is an attempt to study depressive speech linguistically focusing on the linguistic indicators or markers of such type of speech. It mainly aims at specifying the linguistic markers of depression in religious texts and finding out on which linguistic level depression seems to be manifested more in religious texts along with the functions of depressive speech. Accordingly, it is hypothesized that: (1) Religious texts, in English and Arabic, exhibit certain types of linguistic markers such as first-person singular pronoun (i.e. I talk), past tense verbs, the excessive amount of words conveying negative emotions, absolutist words, and metaphor. (2) Linguistic markers of depression are manifested differently on the linguistic levels of the data selected in the two languages.(3) Depressive speech in religious texts serves different communicative functions. The data of the present study are collected from some of the Bible's stories about influential figures of faith and Du'aa Kumayl. After analyzing the data, the study has come up with some conclusions that religious texts exhibit certain linguistic markers of depression. These linguistic markers are manifested differently on the linguistic levels of the data selected in the two languages. Finally, depressive speech serves different communicative functions. These conclusions validate the hypotheses set in the first place.
\end{abstract}

Keywords:

Depression, Depressive Speech, Linguistic Markers, The Bible, Dua'a Kumayl

\section{Introduction}

Language can be separated into two components: content and style. The content relates to what we express - that is, the themes and the underlying meaning or subject matter of statements. The style of language, on the other hand, relates to how we express ourselves, or the "different ways" to deliver the content (Renkema, 2004: 145).

People's linguistic style, or ways of using common words that find their way into most sentences, can actually reveal quite a bit about both their personalities and current situations in which they temporarily find themselves. To put it differently, people convey meaning not only by what they say, but how they say it. For example, when a mother calling her child "Tim please come to the kitchen" and "Tim you get yourself to this kitchen right know", the underlying message ,in both cases, is identical (i.e. come to the kitchen). The variations in the linguistic style of the two sentences convey clearly different meanings about the speaker's psychological state at that particular moment in time (Kasser, 2013: n.p.).

Generally, depression can be defined as a mood disorder that causes a persistent feeling of sadness and loss of interest. It affects how the person feels, thinks and behaves and can lead to a variety of emotional and physical problems. It also affects doing normal day-to-day activities feeling that life is not worth living. Depression can exist as a disease, as a disorder, as a syndrome, as a normal mood state, and as existential position (Parker and Manicavasagar, 2005: 24). 
Traditionally, researchers of depression have looked for causes of depressed expressive behavior within the patient, some focusing on psychological variables, others on biological factors and so on. Little attention is paid to the importance of language and verbalism in depression and studies on linguistic indicators of depression are still challenging.

The language of religious texts seems to be rich data to carry out a linguistic study of depression in an attempt to answer the following questions: (1) What are the linguistic markers of depression in religious texts in English and Arabic? (2) On which linguistic level does depression seem to be manifested more in religious texts in both languages? (3) What are the stylistic functions of depressive speech in religious texts in both languages?

In the light of these questions, the present study tries to achieve the following aims: (1) Specifying the linguistic markers of depression in religious texts in English and Arabic (2) Finding out on which linguistic level depression seems to be manifested more in religious texts in both languages (3) Figuring out the stylistic functions of depressive speech in religious texts in both languages. Thus, it is hypothesized that: (1) Religious texts, in English and Arabic, exhibit certain types of linguistic markers such as firstperson singular pronoun (i.e. I talk), past tense verbs, the excessive amount of words conveying negative emotions, absolutist words, and metaphor. (2) Linguistic markers of depression are manifested differently on the linguistic levels of the data selected in the two languages.(3) Depressive speech in religious texts serves different communicative functions.

The following procedures are adopted: (1) presenting a theoretical background about depression, depressive speech and the linguistic markers of this type of speech. (2) Analyzing (six) extracts of the Bible and Dua'a Kumayl (three for each) according to an eclectic model.

2. Depression and Depressive Speech
Generally, depression can be defined as a mood disorder that causes a persistent feeling of sadness and loss of interest. It affects how the person feels, thinks and behaves and can lead to a variety of emotional and physical problems. It also affects doing normal day-to-day activities feeling that life is not worth living. Depression can exist as a disease, as a disorder, as a syndrome, as a normal mood state, and as existential position (Parker and Manicavasagar, 2005: 24).

Depressive speech, according to Welch ( 2011: 8) is poetic. Depressed people are eloquent, even when they feel empty at their emotional core, hopeless, helpless or devoid of personhood. It should be noted, however, it is of course possible to use a language associated with depression without actually being depressed.

\section{Linguistic Markers of Depression}

The link between depression and language was first underlined by Ellis in 1977. Ellis was a psychotherapist and linguist; that is why he understood the importance of language and verbalism in depression. He (2007: 14) states that our emotions "interact with our verbalizations, which quickly follow our silent thinking-feeling level". As such, speech is significantly influenced by depression. Smirnova et al. (2013) showed that in the case of depressive patients, language presents a specific pattern on stylistic and grammar fields. Considering language, the practical influence of depressive mood on linguistic style is present on different linguistic dimensions or levels:

\subsection{The Grammatical Level}

On the grammatical level, common occurrences of first-person singular pronoun are clear in depressive speech. That is, the speech is self-focused. More often, 'depressed' users tend to use self-related words such as $I$, me, myself, mine. Moreover, depressive speech exhibits extensive past tense use for verb actions, inverted word order for topic, presence of emphasis, presence of short, impersonal, truncated and arid sentences and repetition (Martins et al., 2020: 406). 


\subsection{The Lexico-Semantic Level}

The lexico-semantic level attests certain linguistic markers of depression:

\section{a. Negative Emotion Content Words:}

What constitutes the major part of the content is the content words that have a lexical meaning. They are nouns, verbs, adjectives and adverbs. Depressive speech contains excessive amounts of words conveying negative emotions to describe how they feel, specifically negative adjectives and adverbs such as lonely, sad, miserable, bad, sad, hopeless, aching, lost, worthless, useless, stupid, stuck, untethered, adrift, hurting, alone, afraid, unsure, insecure, despair, black and so on. (Sudip et al., 2019: 223). In this way, depressed users tend to have an overall negative connotation of their texts.

\section{b. Absolutist Words:}

In a recent study on absolutist thinking, which is considered a cognitive distortion by most cognitive therapies for anxiety and depression, Al-Mosaiwi and Johnstone (2018) show that depressive speech contains excessive amount of more absolutist words such as absolutely, all, always, complete, completely, constantly, definitely, entire, ever, everyone, everything, full, must, never, totally, whole, never, every.

\section{Metaphor}

Metaphors are one of the linguistic tools used to express feeling and convey depression. The 'sufferer' uses it to linguistically manifest his experience, emotions and suffering from depression as in it is really a black cloud (McMullen and Conway, 2002: 171).

\section{The Model of Analysis}

In accordance with the theoretical background, the following eclectic model is utilized for the data analysis of the present study. This model is based on literature review about the linguistic markers of depression viewed earlier:

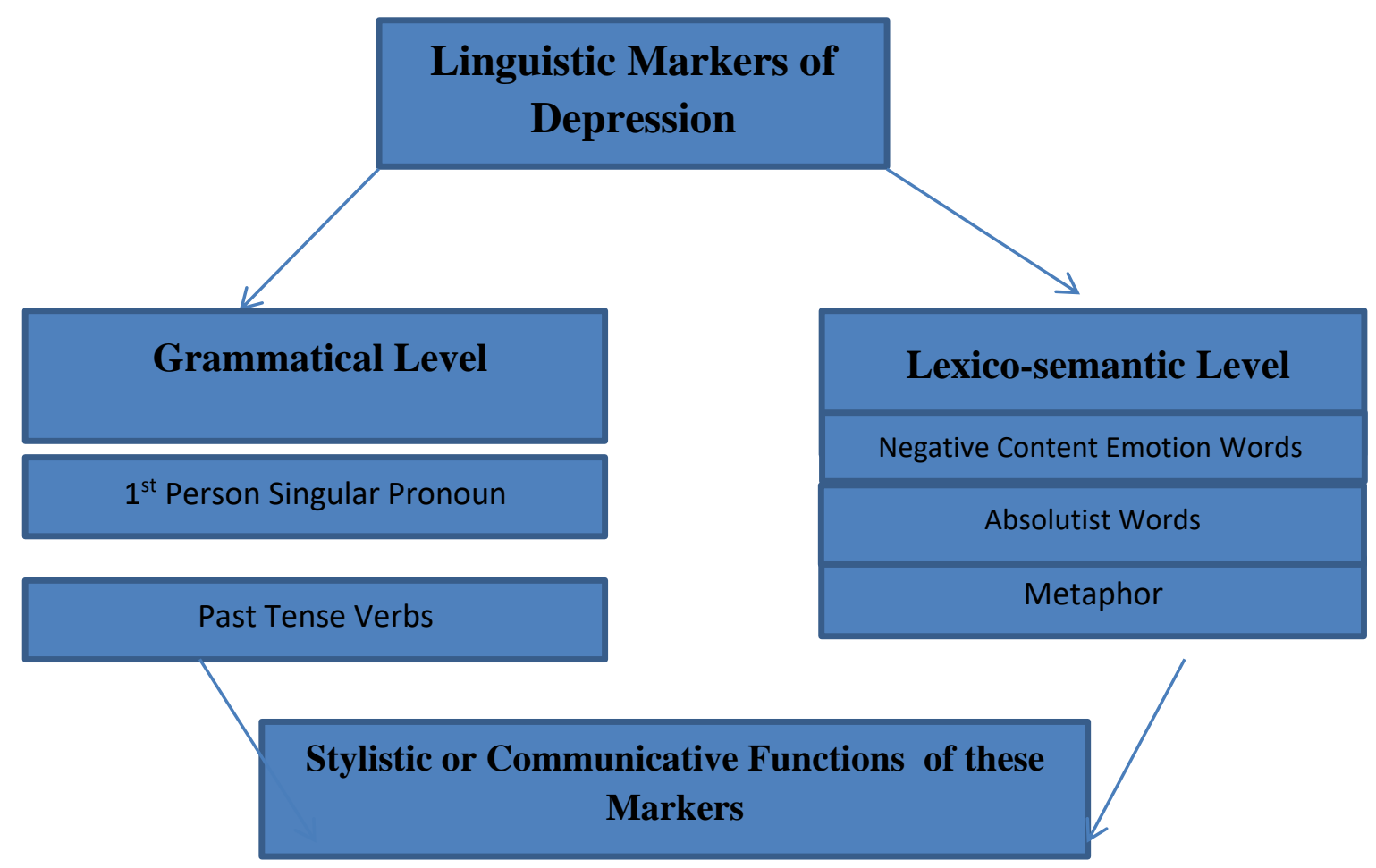

Figure (1): The model of Analysis 


\section{Data Analysis}

Although the Bible does not use the word "depression" except in a few translations and verses, it is often referenced by other words with similar meanings, such as "despairing", "downcast", "mourning" "troubled" "miserable" and "brokenhearted" and others (Brownlow, 2014: n.p.). There are a number of stories about godly, influential men and women of faith, who struggled and battled through dark times of hopelessness and depression Three of these stories about depression are selected to be analyzed linguistically according to an eclectic model:

\section{Extract (1)}

David was troubled and battled deep despair. In many of the Psalms, he writes of his anguish, loneliness, fear of the enemy, his heart-cry over sin, and the guilt he struggled with because of it:

"My guilt has overwhelmed me like a burden too heavy to bear." Ps. 38:4

The extract above exhibits certain linguistic markers of depression on different linguistic levels. On the grammatical level, first person singular pronouns, "my' and "me", are used more than other pronouns. This is a sign of being inwardly focused, as is often the case of someone battling depression because of his sin.

On the lexico-semantic level, the negative content emotion words "guilt", "overwhelmed", "burden", "heavy" and "bear" occur to indicate his negative emotionality towards the situation he experiences.

Metaphor, as linguistic marker of depressive speech, is clear in the speaker's sentence 'My guilt has overwhelmed me" to express his suffering and anguish from his guilt. The "guilt" here is represented as having the oppressive ability to hurt the speaker.

\section{Extract (2)}

Job suffered through great loss, devastation, and physical illness. This righteous man of God lost literally everything. So great was his suffering and tragedy:
"Terrors overwhelm me...my life ebbs away, days of suffering grip me. Night pierces my bones, my gnawing pains never rest." Job 30:15-17

On the grammatical level, first person singular pronouns "me" and "my" occur five times as a marker of depression. This self-referential language suggests that the speaker is more concerned with himself (i.e. his suffering and tragedy), and less connected with others.

On the lexico-semantic level, negative emotionality is salient by means of these content words: "terrors", "overwhelm", "suffering", "grip", "ebb away", "pierces", "gnawing" and " pains", . Within the same level, the absolutist word "never" elucidates the speakers absolute thinking which is, in turn, a linguistic marker of depressive speech.

Further, the above extract is rich with metaphor. It is manipulated four times to convey the suffering the speaker experiences in a fully explicit manner by means of that poetic device. First, he depicts "terror" as having a superior force to overpower him. Second, the "ebb away" of his life metaphorically refers to the change of his life to a worse state rather than the literal meaning of falling from higher to a lower position. Third, in "the days of suffering grip me", the speaker metaphorically refers to his helplessness of getting rid of his suffering. Fourth, the speaker in "night pierces my bones", metaphorically depicts his sickness.

Extract (3)

Jeremiah wrestled with great despair, loneliness, feelings of defeat, and insecurity. He is known as the weeping prophet. He suffered from constant rejection by the people he love. God had called him to preach, yet forbidden him to marry and have children. He was poor and ridiculed that he lived alone and ministered alone:

"Cursed be the day I was born... why did I ever come out of the womb to see trouble and sorrow and to end my days in shame?" Jeremiah 20:14, Jeremiah 20:18 
On the grammatical level, the use of the first person singular pronouns three times explains that the speaker is concerned with his own situation and has no interest in others because he lived alone and was rejected by his people. That is why his speech displays a sense of exclusion or being excluded. The second linguistic marker is the use of the past tense. It occurs twice "was" and "did" to show the speaker's discontent and complaint about his situation because of his failure or defeat.

Examining the lexico-semantic level, the words "Cursed", "trouble", "sorrow", "shame" are the content words that linguistically reflect the negative emotions that indicate how the speaker's speech is depressive. Such words are manipulated to depict his depression with the way he lives.

The poetic semantic device is salient in "to see trouble and sorrow". This phrase is metaphorical since the trouble and sorrow are not physical entities and thus, cannot be seen. They can only be felt and experienced. However, it is manipulated by the speaker to express that he is in a constant struggle and insecure.

There are stylistic or communicative functions behind such markers or the depressive speech in the three extracts selected from The Bible. They represent a prayer of complaint in the crisis.

\section{Arabic Data}

Dua'a Kumayl or Kumayl's supplication is one of the most well-known supplications among the followers of The School of Ahl al-Bayt (peace be upon them). They recite it every thursday and on the night of the half of Shaban. It is the supplication of Al-Khidr (peace upon him) and it was taught by Imam Ali bin Abi Talib (peace be upon him). According to its narrations, it is said to be a very valuable treasure as it contains profound meanings with educational lessons and selfeducation. It strengthens in the believer the spirit of slavery and orientation to God. This supplication is a kind of stereotyped format taught by Imam Ali or Al-Kidhr to believers to pray or supplicate. In this way, the speaker in the extracts analyzed below is any believer who supplicate seeking forgiveness from God:

Extract (4)

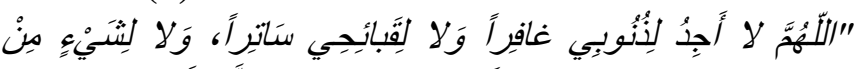

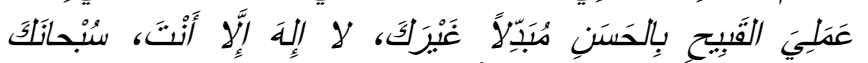

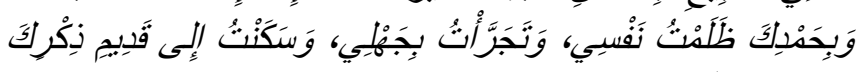

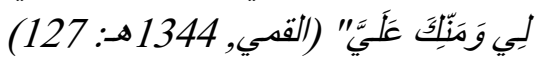

"O Allah, I do not find other than Thee any one able to pardon my sins, nor to conceal my loathsome acts, nor have I anyone except Thee to change my evil deeds into virtues; There is no god but Thou; glory and praise be to Thee, I have made my own soul to suffer; I had the audacity, by my ignorance, relying upon my past remembrance of Thee and Thy grace towards me." (Web Resource 1)

This extract reveals an address to Almighty Allah in which the speaker is seeking for forgiveness about the sins he committed. He makes use of depressive speech to convey something about his condition. This is revealed by the linguistic tools of depression manipulated in the text. On the grammatical level, the first person pronoun occurs in different forms:

- Implicit pronoun (I) in the verb أجد / find

/I did wrong, تجر أت I had the audacity, سكنت /I relied upon)

- Pronouns connected to nouns: (Al-Ya'a):

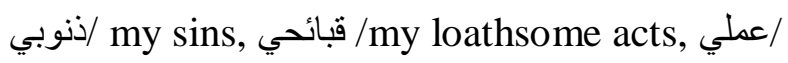
my deeds, روحي/my soul, جطي /my ignorance)

- Pronouns connected to prepositions: (علي ,لي) to me/)

Past tense verbs and actions in: ظلمت /I did wrong, تجرأت I had the audacity, سكنت /I relied upon) manifest that the speaker is concerned with the past experiencing regret and blaming himself for his bad deeds.

On the lexico-semantic level, negative emotion words occur: فبائحي, القبيح-loathsome, ظلمت / did wrong, my ignorance/جلي. These words negatively describe the disgusting state the 
speaker feels about his deeds. Metaphorically, in Allah's remembrance and grace for the speaker, are represented as a comfort and quietness resort for which the speaker resorted or relied on doing sins.

\section{Extract (5)}

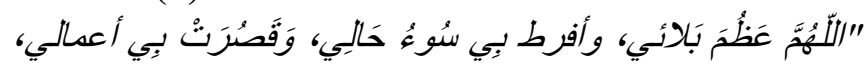

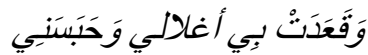

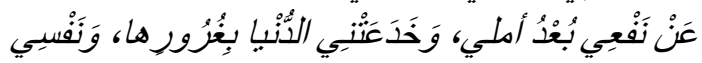

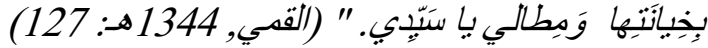

"O Allah, My trials and sufferings have increased, my evilness has worsened, my good deeds have diminished, and the chains of my misdeeds have become firm; and the remoteness of my hopes have restrained me from benefitting myself by good deeds; and the world has deceived me with its allurements and my own self has been affected by treachery and procrastination." (web Resource 1).

On the grammatical level, the extract, again, is a self-centered talk. First person singular pronouns occur in the following forms:

- Pronouns connected to the verb (Al-Ya'a): / imprisoned me, خدعنتي / deceived me.

- Pronouns connected to the noun: (AlYa'a): بلائي/ my sufferings, حالي/my condition, أغلالي / my chains, فعمي / my deeds, أعمالي benefit, أملي/my hope, نفسي/myself, مطالي/my / my procrastination, سيدي/ my lord

- Pronouns connected to prepositions: (Al-ya'a)

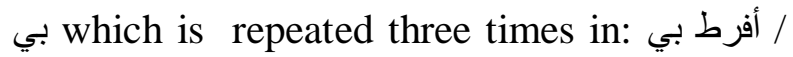

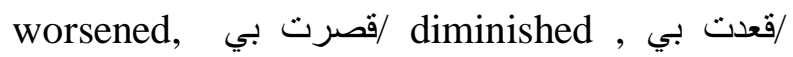
became firm)

Within the same level, past tense verbs of actions, اعظم increased, أفرط /worsened, قعدت/became firm, حبسني/imprisoned, خدعني/deceived, represent a linguistic marker of depression manipulated by the speaker addressing Almighty Allah explaining his helplessness.

On the lexico-semantic level, depressive speech is evidently indicated by means of the following negative content emotion words: أغلالي /chains,

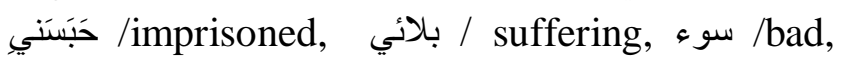
/deceived.
Metaphorically, in "قعدت بي أغلالي" / "the chains of my misdeeds have become firm", sins are represented as chains that make the speaker helpless and powerless.

\section{Extract (6)}

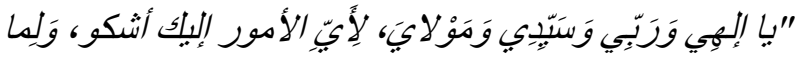

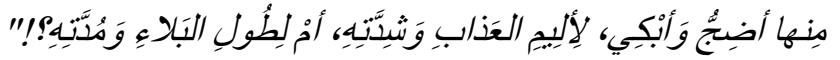

$$
\begin{aligned}
& \text { (القهي, 1344هـ: 130) }
\end{aligned}
$$

"O' my God, my Lord, my King, and my Master, which of these matters shall I complain to Thee and for which of them shall I bewail and weep? shall I bewail for the pains and agonies of the punishment and their intensity, or for the length of sufferings and their duration?" (Web Resource 1)

Examining the grammatical level, first person singular pronouns occurrence, seven times in the extract, linguistically indicates the speaker depressive mood by which he expresses his own imaginative future condition to Almighty Allah and the way things are going to turn out to be, as Almighty Allah promised, because of his current miserable situation:

- Implicit pronouns connected to the verbs: أشكو/I complain, أضج/ I bewail, أبكي /I weep)

- Pronouns connected to nouns (Al-Ya'a): ألهي/O' my God , سبدي /my Lord, سبي /my King, and مو لاي /my Master)

On the lexico-semantic level, four negative content emotion words occur: أليم أبكي/weep, /painful, العذاب /torture, العذاب/sufferings. Thus, the words choice marks a depressive tone in the extract. These words are manipulated to denote the helplessness of the speaker in the Judgment Day.

As for the stylistic or communicative functions of the depressive speech in Dua'a Kumayl, the three extracts reflect the speakers urgent need for forgiveness. That is, it is an address to Almighty Allah seeking forgiveness or istighphar.

6. The Results of the Analysis 
Table 1. Linguistic Markers of Depression in The Bible

\begin{tabular}{|c|c|c|c|c|c|c|c|c|c|}
\hline \multirow[t]{3}{*}{$\begin{array}{l}\text { No. of } \\
\text { Extract }\end{array}$} & \multicolumn{2}{|c|}{$\begin{array}{c}\text { The Grammatical Level } \\
\text { Markers } \\
\text { GL }\end{array}$} & \multicolumn{3}{|c|}{$\begin{array}{c}\text { The Lexico-Semantic Level } \\
\text { Markers } \\
\text { L-SL }\end{array}$} & \multicolumn{4}{|c|}{$\begin{array}{c}\text { Frequency and Percentage } \\
\text { Freq. \& Perc. }\end{array}$} \\
\hline & \multirow{2}{*}{$\begin{array}{c}\mathbf{1}^{\text {st }} \text { person singular } \\
\text { pronoun }\end{array}$} & \multirow{2}{*}{$\begin{array}{l}\text { Past } \\
\text { tense } \\
\text { verbs }\end{array}$} & \multirow{2}{*}{$\begin{array}{l}\text { Absolutist } \\
\text { words }\end{array}$} & \multirow{2}{*}{$\begin{array}{l}\text { Negative } \\
\text { Emotion } \\
\text { Words }\end{array}$} & \multirow[t]{2}{*}{ Metaphor } & \multicolumn{2}{|c|}{ GL } & \multicolumn{2}{|c|}{ L-SL } \\
\hline & & & & & & Freq. & Perc. & Freq. & Perc. \\
\hline 1 & 2 & $\mathbf{0}$ & $\mathbf{0}$ & 5 & 1 & 2 & $25 \%$ & 6 & $75 \%$ \\
\hline 2 & 5 & $\mathbf{0}$ & 1 & 8 & 4 & 5 & $27.7 \%$ & 13 & $72.2 \%$ \\
\hline 3 & 3 & 2 & 1 & 4 & 1 & 5 & $45.4 \%$ & 6 & $54.4 \%$ \\
\hline Total & 10 & 2 & 2 & 17 & 6 & 12 & $32.4 \%$ & 25 & $67.5 \%$ \\
\hline
\end{tabular}

Table 2. Linguistic Markers of Depression in Dua'a Kumayl

\begin{tabular}{|c|c|c|c|c|c|c|c|c|c|}
\hline \multirow[t]{3}{*}{$\begin{array}{c}\text { No. of } \\
\text { Extract }\end{array}$} & \multicolumn{2}{|c|}{$\begin{array}{c}\text { The Grammatical Level } \\
\text { Markers } \\
\text { GL }\end{array}$} & \multicolumn{3}{|c|}{$\begin{array}{c}\text { The Lexico-Semantic Level } \\
\text { Markers } \\
\text { L-SL }\end{array}$} & \multicolumn{4}{|c|}{$\begin{array}{c}\text { Frequency and Percentage } \\
\text { Freq. \& Perc. }\end{array}$} \\
\hline & \multirow{2}{*}{$\begin{array}{c}1^{\text {st }} \text { person singular } \\
\text { pronoun }\end{array}$} & \multirow{2}{*}{$\begin{array}{l}\text { Past } \\
\text { tense } \\
\text { verbs }\end{array}$} & \multirow{2}{*}{$\begin{array}{l}\text { Absolutist } \\
\text { words }\end{array}$} & \multirow{2}{*}{$\begin{array}{l}\text { Negative } \\
\text { Emotion } \\
\text { Words }\end{array}$} & \multirow[t]{2}{*}{ Metaphor } & \multicolumn{2}{|c|}{ GL } & \multicolumn{2}{|c|}{ L-SL } \\
\hline & & & & & & Freq. & Perc. & Freq. & Perc. \\
\hline 4 & 11 & $\mathbf{3}$ & $\mathbf{0}$ & 4 & 1 & 14 & $73.6 \%$ & 5 & $33.3 \%$ \\
\hline 5 & 14 & 6 & $\mathbf{0}$ & 5 & 1 & 18 & $75 \%$ & 6 & $25 \%$ \\
\hline 6 & 6 & 0 & 0 & 4 & 0 & 6 & $60 \%$ & 4 & $40 \%$ \\
\hline Total & 31 & 9 & 0 & 13 & 2 & 38 & $71.6 \%$ & 15 & $28.3 \%$ \\
\hline
\end{tabular}

As far as the findings of the study are concerned, the above tables clearly show the occurrence of certain linguistic markers of depression in the selected religious texts such as first-person singular pronouns, past tense verbs, the excessive amount of words conveying negative emotions, absolutist words, and metaphor.

Moreover, the tables show the different manifestation of the linguistic markers of depression in the selected extracts from the two religious texts. In the Bible, linguistic markers of depression are more dominant on the lexicosemantic level than on the grammatical one. By contrast, in Dua'a Kumayl, they are more dominant on the grammatical level rather than on the lexico-semantic one.

\section{Conclusions:}

1. Concerning the form or the style of the language of religious texts, depressive speech can be figured out by means of certain linguistic markers such as the excessive use of the first person singular pronouns, past tense verbs, negative emotion content words, absolutist words and metaphor. This outcome validates hypothesis no. (1) ) which reads as religious texts, in English and Arabic, exhibit certain types of linguistic markers such as first-person singular pronoun (i.e. I talk), past tense verbs, the excessive amount of words conveying negative emotions, absolutist words, and metaphor.

2. In the extracts of the Bible, the linguistic markers of depression are manifested more on the lexico-semantic level. By contrast, in the extracts of Dua'a Kumayl, the linguistic markers of 
depression are manifested more on the grammatical level. This outcome proves hypothesis no. (2) which reads as linguistic markers of depression are manifested differently on the linguistic levels of the data selected in the two languages.

3. As for the content or the message of the religious texts selected, depressive speech is manipulated in such texts as a means for a further end. That is, it has certain stylistic and communicative functions such as a prayer of complaint, seeking forgiveness from God i.e. istigphar, and praise. This outcome verifies hypothesis no. (3) which reads as Depressive speech in religious texts serves different communicative functions.

\section{References}

[1] Al-Mosaiwi, M. and Johnstone, T. (2018) In an Absolute State: Elevated Use of Absolutist Words Is a Marker Specific to Anxiety, Depression, and Suicidal Ideation. Clinical Psychological Science. Available at: https://doi.org/10.1177/216770261774707 $\underline{4}$.
[2] Brownlow, J. (2014). Honey and the Rock: Recovery, Life and God. Brownlow. Available at:

https://www.amazon.com/Detection-

Neurological-Disorders-Learning-

Technologies/dp/1522585672.

[3] Ellis, A. (2007). General Semantics and Rational-Emotive Therapy: 1991 Alfred Korzybski Memorial Lecture. ETC: A Review of General Semantics, 64(4), 301319. Available at: www.generalsemantics.org/wpcontent/uploads/2011/04/gsb-58- ellis.pdf.

[4] Hindson, Edward E., Edward Dobson, Charles Feinberg, Woodrow Kroll, and Harold Willmington (eds.). (1994). King James Version Bible . Nashville: Thomas Nelson Publishers.

[5] M. Jose, J., Yilmaz, E., Magalhães, J., Castells, P., Ferro, N., Silva, M. and Martins, F. (2020). Advances in Information Retrieval. Switzerland: Springer.

[6] McMullen, L. M and Conway, J. B. (2002). Conventional Metaphors for Depression. In Fussel, S. (ed.), The Verbal Communication of Emotions: Interdisciplinary Perspectives. Mahwah, NJ: Lawrence Erlbaum:167-181

[7] Parker, G. and Manicavasagar, V. (2005). Modelling and Managing the Depressive Disorders: A Clinical Guide. Cambridge: Cambridge University Press.

[8] Renkema, J. (2004). Introduction to Discourse Studies.

Amsterdam/Philadelphia: John Benjamins Press.

[9] Smirnova, D., Sloeva, E., Kuvshinova, N., Krasnov, A., Romanov, D., and Nosachev, G. (2013). 1419 - Language changes as an important psychopathological phenomenon of mild depression. In European Psychiatry (Vol. 28, p. 1). Elsevier Masson. Available at: 
https://doi.org/10.1016/S0924-

9338(13)76454-X

[10] Sudip, P. ; Pallab, B. and Arindam, B. (eds.). (2019). Early Detection of Neurological Disorders Using Machine Learning Systems. India: IGI Global.

[11] Welch, E. T. (2011). Depression: Looking Up from the Stubborn Darkness. Greensboro: New Growth Press.

\section{Arabic Resources:}

القمي, عباس. (1344). مفاتيح الجنان. قم: برسنش.

\section{Web Resources:}

[13] https://najafi.yoo7.com/t2923-topic (Accessed in 23/12/2020) 